\title{
高品質なものづくりを指向した 生産技術の情報化*
}

\author{
小島史夫**
}

Information Oriented Production Technology for High Quality Product/Fumio KOJIMA

Key words: quality, production technology, information, CAE, vision system, precision control, knowledge

\section{1.は じめに}

日本のものづくりの競争力の一つとして品質が注目され ている．自動車部品においては，グローバルに展開する自 動車メーカへ同一品質の部品を迅速に供給することが，競 争力を増すための要件の一つであり, 生産現場でも, これ まで取り組んできた $100 \%$ 良品を顧客に納入する活動を基 本とし, 小型化, 軽量化, 高精度化, 低コスト化を指向し た生産技術開発が行われており，技術革新の著しい情報技 術もコア技術の一つとして，その適用が進んでいる. 以 下，高品質なものづくりを実現するための生産技術の取り 組みの状況を情報活用の観点から述べる.

\section{2. 品 質と情 報}

\section{1 高品質化への取り組み}

生産の立場から高品質化に向けての取り組みの概要を図 1 に示す.

製品開発段階での高品質化, すなわち設計品質は, 魅力 ある品質を創造するための活動ともとらえることができ る. 生産準備活動もこの段階から, 生産技術の視点で魅力 ある品質を製品へ創造する活動が, 製品開発とコンカレン トに行われる。具体的には, 作りやすさ・品質確保のしや すさを意図した生産要件の反映, 製品開発へ参画し, 製品 仕様および生産環境を考慮した材料選定や, 生産工程簡略 化のための標準化活動, 顧客ニーズの多様化と生産性・高 品質を両立させるために部品の組み合わせによる多種化や 組付け基準の共通化などによって多種製品であっても作り

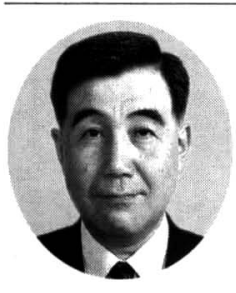

*原稿受付 平成 15 年 10 月 7 日

**正会員株式会社デンソー(刏谷市昭和町 1-1)

1979 年東京工業大学大学院理工学研究科修了. (株)日本電装（理デンソー）入社後, 生産システ 么開発に従事. 2000 年より生産技術開発部部 長. 工学博士.
やすい生産システムを実現する多種整理などの活動と, 設 計品質を先取りし生産品質へ反映させる, 生産性向上およ び生産品質向上を目指した, 新工法開発, 新設備開発など の早期生産準備活動が行われる.

生産活動の段階での高品質化, すなわち生産品質は, 生 産工程で設計品質を長期間・安定的に高品質な部品・製品 へ転写し, 顧客に 100 \% 良品を納めることである。このた めには, 基本的に各工程では不良品を作らないこと, 生産 システムとしては, 万が一発生した不良品の流出防止を図 ることが重要となる. 前者は工程能力をバラッキ少なく安 定的に維持・向上すること, および工程の突発異常による 大量不良発生を未然防止することが求められ, 設備自動 化, 作業の標準化, 作業者自身の品質検知能力の向上, 設 備予防保全, ポカヨケによる突発異常の防止などが行われ る. 後者は各工程で確実に流出防止を図る品質の関所を設 けることと, 全工程を通して不良品の確実な流出防止を行 う生産システム面からの取り組みが求められ, 各工程で検 査工程の導入, 検査精度の向上, 生産システムを構成する 工程全体で確実に不良流出を防止する QA ネットワークに

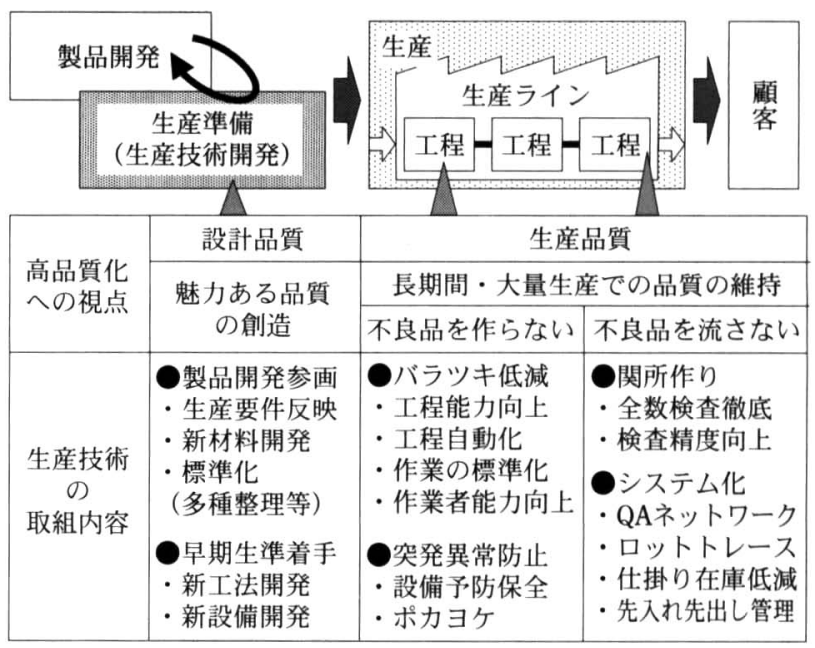

図 1 高品質化への生産技術の取り組み 


\begin{tabular}{|c|c|c|}
\hline $\begin{array}{c}\text { 仕事の } \\
\text { 流れれ }\end{array}$ & 理対象 & 処理結果（品質向上） \\
\hline $\begin{array}{l}\text { 情報の } \\
\text { 役割 }\end{array}$ & $\begin{array}{l}\text { 可視化手法(1) } \\
\text { (モデル化, 特徵認識・抽出) }\end{array}$ & $\begin{array}{c}\text { 処理・操作手法(2) } \\
\text { (定式, アルゴリズム, データベース, 知識) }\end{array}$ \\
\hline
\end{tabular}

\begin{tabular}{|c|c|c|c|}
\hline \multirow{2}{*}{$\begin{array}{l}\text { 高品質化 } \\
\text { への視点 }\end{array}$} & 設計品質 & \multicolumn{2}{|c|}{ 生産品質 } \\
\hline & 魅力ある品質の創造 & 不良品を作らない & 不良品を流さない \\
\hline \multirow{4}{*}{$\begin{array}{ll} & \text { バイト } \\
\text { 情 } & \text { メ゙ガ } \\
\text { 報 } & \text { バイト } \\
\text { 処ロ } & \text { キロ } \\
\text { 理 バイト } \\
\text { 量 } \\
\text { バイト } \\
\text { (対象) }\end{array}$} & 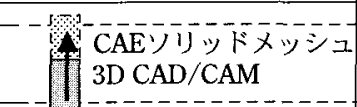 & 形状 & 3次元 \\
\hline & 2D CAD/CAM & 1 特徵量 時系列 & ? \\
\hline & & $\mathrm{ON} / \mathrm{OFF}$ & $1 \begin{array}{l}\mathrm{QR} \\
\text { バーコード }\end{array}$ \\
\hline & $(\mathrm{CAD} / \mathrm{CAM} / \mathrm{CAE})$ & （加工制御） （設備診断） & （外観検査）（認識媒体） \\
\hline $\begin{array}{l}\text { 情報を活 } \\
\text { 用した生 } \\
\text { 産技術例 }\end{array}$ & $\begin{array}{l}\text { 口製品開発参画（製造情報） } \\
\text { ・組立製造性評価法(2) } \\
\text { ・加工CAE〔事例〕 (1)(2) } \\
\text { ・型ラピッドツーリング (3次元) (2) }\end{array}$ & 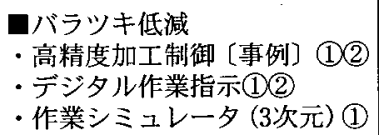 & $\begin{array}{l}\text { 口関所作り '(計測高感度化) } \\
\text { - 自動外観計測 [事例] (1) } \\
\cdot \text { 高精度計測技術(1)(2) } \\
\text { - CAT (3次元) (2) }\end{array}$ \\
\hline \begin{tabular}{|c|} 
手洼 \\
(1):可視化 \\
(2):処理·操作
\end{tabular} & $\begin{array}{l}\text { 口早期生準着手 (設計情報) } \\
\text { ・新規設備開発 (制御ソフト, } \\
\text { シミュュレーション) (1)(2) }\end{array}$ & $\begin{array}{l}\text { 口突発異常防止 } \\
\text { ·設備診断 (多種情報) (2) } \\
\text { ·自己診断・修復機器(1)(2) }\end{array}$ & 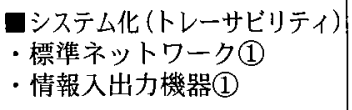 \\
\hline
\end{tabular}

図 2 高品質化と情報活用

よる工程設計，品質データに着目したロットトレース，検 出時問短縮のための仕掛り在庫低隇や先入れ先出しなどが 行われる.

\section{2 高品質化と情報}

高品質化の取り組みは，情報に着目し整理すると，図 2 に示すように，製品・部品などの処理すべき対象を要求品 質を的確に表現する可視化手法によって認識し，要求との 差分から，处理・操作手法によって，加工・組立・検査の いずれか，あるいは複合された手段によって处理される内 容を決定し，品質向上された処理結果を得る仕事の流れ， と表すことができる。この仕事の流れでは，可視化するた めにはモデル化, 特徽認識・抽出の手法, 処理・操作のた めには定式化，アルゴリズム化，データベース化，知識化 などの情報処理技術を生産技術に積極的に融合させること が重要であり, 品質面での競争力となっている. 高品質化 の各視点での情報処理量の状況を事例で示すが，いずれも 増加する傾向にあることがわかる，例えば，視覚装置を用 いた外観検查では 2 次元のモノクロ画像・2 值化处理から カラー画像処理へ, 最近では 3 次元カラー画像处理へと推 移している．画像処理技術の進化によって情報処理量が増 大して扔り，これによって外観検查の対象範囲が増加し活 用が増えている。情報技術の進化による処理能力および処 理速度の大幅な向上が，高品質化への取り組みを加速させ ているともいえる.

具体的な可視化および処理・操作の技術事例を図中に示 すが，単なる情報処理システムの展開ではなく，現場の人 の作業を支援する，人の作業と強調する，人の能力を自動
化して機械に組み込み代替するなど，現地現物を基本に情 報技術をうまく活用した技術が多いのが特徴である。

\section{3. 生産技術の情報化による高品質化}

本節では前節で取り上げた情報化を指向した生産技術開 発による高品質化の事例を紹介する.

\section{1 加工 CAE}

製品開発段階で加工時の品質・生産性をコンピュータシ ミュレーションで予測し，設計仕様と比較して必要に応じ て製品仕様や型仕様を变更し，事前に高品質・高生産性を 実機試作レスで実現する加工 CAEの赛用化が，プレス， 冷鈠，ダイカスト，モールドなどの型物部品を中心に進ん でいる.・加工硬化や成形時の充填不良による強度低下や気 密性不足などが，従来の寒型確認や尃門家の知識依存か ら，定量的かつ迅速に現物を模擬した品質確認が行えるよ うになり，製品設計品質の早期完成度向上に貢献してい る.

図 3 はアルミダイカスト分野での CAE を用いて機密性 を向上させた事例を示している. 3 次元 $\mathrm{CAD}$ による設計 モデルを加工 CAEに展開し，流動凝固解析の結果からひ け巣の発生懸念が判明し, それを防止するために流動凝固 解析により薄肉化・肉盗みを行い，その結果生じる強度低 下を強度解析によってリブで補強する構造設計を行い，設 計図面へ反映している。この一連の設計作業が加工 CAE により容易となりつつあるが，正確な結果を得るために は, 可視化技術としての計算機モデルの開発, 適切な処理 をするための材料デー夕の充実が必要である. 図 3 に示し 
たアルミ溶湯の充填性に起因する鋳造品質解析 ${ }^{1}$ は図 4 に 代表される流れの可視化実験 ${ }^{2} に よ り$ 実際のアルミ溶湯の 流れの挙動を明らかにしこれれから得られた知見を計算方 法（定式化，アルゴリズム）の見直しに反映している．多 数個取りを想定した可視化モデルの 3 力所の湯路は同形状 であるが，中央部入口の細くなった部分まで溶湯がまず入 り，その抵抗で両端部に流れ，その時間で中央部の細く なった部分は固まり始めることによって両端が流れやすく なるメカニズムを特定した。この知見を解析手法に反映し 実用化した.

加工 CAE の適用領域の拡大と精度向上が期待されるが, 残された領域は対象部品の複雑さ, 挙動の定式化の難し さ，高精度化のための要素分割数増加への対応など, 情報 技術面，加工技術面ともに課題が多く，開発コスト低減， 開発期間短縮のために企業の枠を越えた活動が期待され る。

\section{2 画像インライン計測技術を導入した高精度加工}

燃料噴射製品は，燃費向上，排ガス清浄化のために，燃 料噴射量を高精度で調量することが求められ，バルブ部品 加工の高精度化がますます重要となりつつある。高精度加 工は，現状では加工中あるいは加工後に加工精度を計測 し，その結果を加工機にフィードバックする方式が採用さ れている.この場合, 長さ, 径といった 1 次元寸法をマイ クロメータ, レーザ測長器などの 1 次元計測によって制御 パラメータを直接可視化しているが, 要求部位の複雑化お よび精度向上によって, 求められる制御パラメー夕の直接 可視化が従来技術では難しくなり，間接的な計測情報を用 いて可視化し，定式化あるいはアルゴリズム化された処理 によって所要の制御パラメータへ変換し, 加工精度向上を 実現する制御技術開発が行われている ${ }^{3)}$.

図 5 はバルブのシート面を加工するために開発された インライン画像計測を用いた加工制御システムの構成を示 す.この加工ではシート面とシート加工面の交点となる シート径の高精度加工が求められるが，従来の作業者が投 影機で側面からシルエット画像を用いて計測する可視化手 法では, 測定精度が低く, 全数計測が難しく, 要求精度へ 対応できず，図 6 に示す画像計測による計測手法を開発 した、シート径を全数インライン自動計測する手法がない ため,リング照明によるシート面での反射光によってシー ト径部分に現われるハイコントラスト画像を CCD カメラ で軸方向正面から観察し, シート径部近傍の 2 次元画像と して可視化, 面積計測処理を行いシート径を求める手法を 開発した。間接的な計測のため，計測画像に含まれるワー クの傾きや長短，照明変化や加工油の付着などによる䛊差 情報を低減させることが不可欠で，そのための処理アルゴ リズムも開発し，従来計測法に比べ 5 倍の計測精度を実現 した.

本画像計測技術に同時研削を行う研削ユニットなどを加 えた加工制御システムのシート径精度を図 7 に示すが,

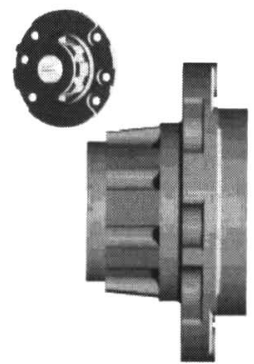

初期形状/3D CAD

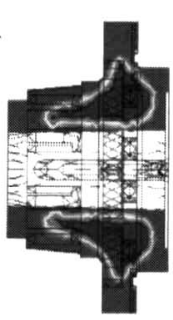

初期形状/CAE

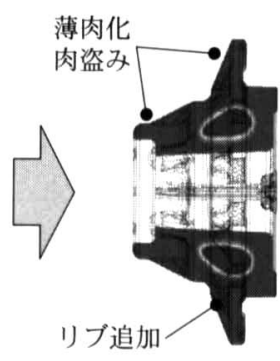

改良形状/CAE
図 3 ダイカスト $\mathrm{CAE}$ 解析事例
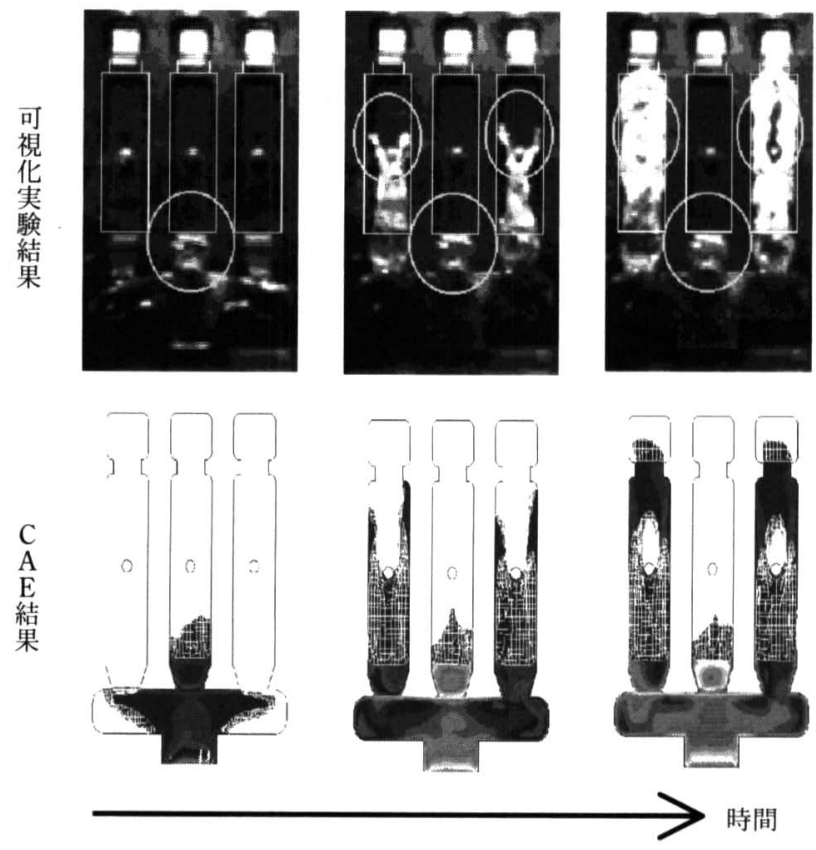

図 $4 \mathrm{CAE}$ 精度向上のための可視化実験

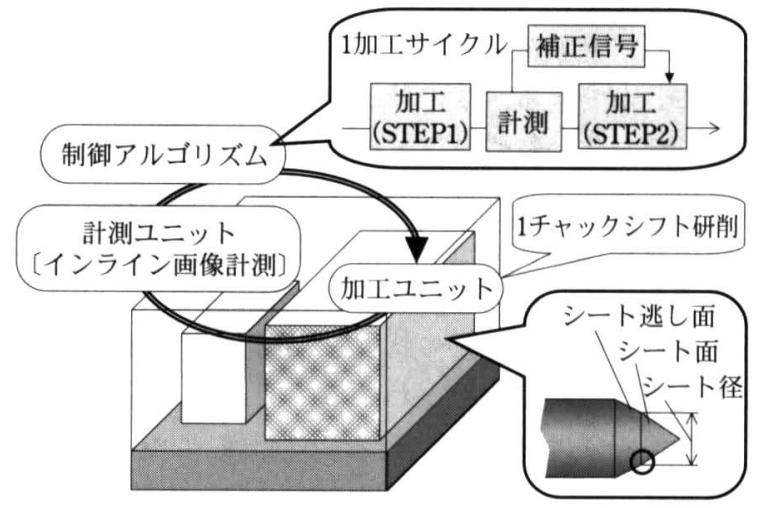

図 5 インライン画像計測を用いた加工制御システム

シート径加工精度が 3 倍に向上した。

今後も制御パラメータの高信頼性化の必要性は高く, 加 工方法の特徴に着目し, 間接的計測量の変換により所要の 制御パラメータを得る手法の開発は増加すると思われる。 


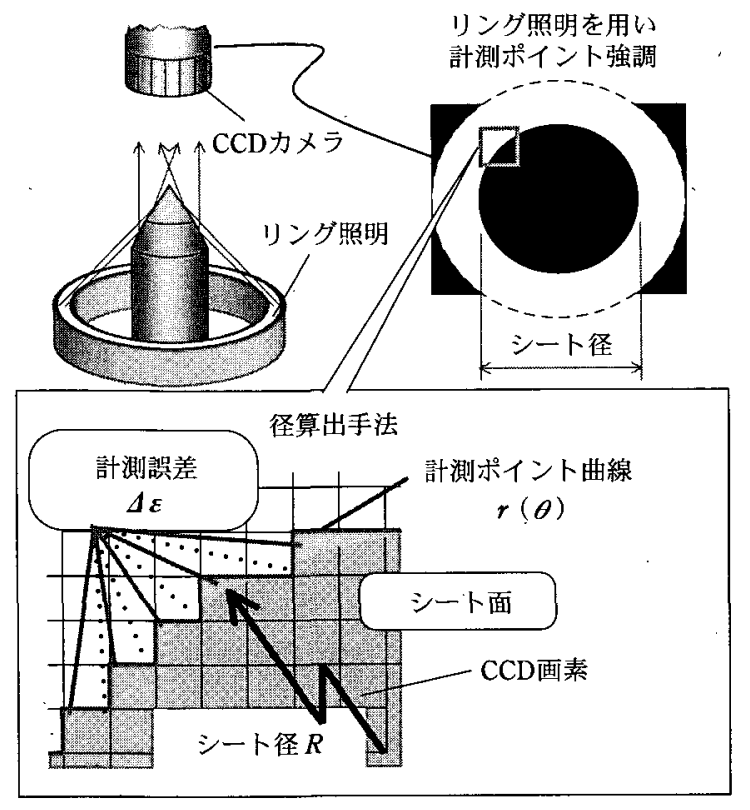

图 6 画像インライン計測技術

\section{3 作業者の知識を組み込んだ加工制御}

前項で取り上げた事例は入出力情報の関係が $1: 1$ の手 法である．高精度な制御を行う手法として，多様な計測情 報を用いて，作業者の経験則，ノウハウからなる知識べー スを用いて稼動状態を予見して複数の制御アルゴリズムを 起動させ, 複数の制御パラメータを操作する, 入出力情報 の関係が $\mathrm{N}: \mathrm{M}$ の高精度制御手法も開発されている。

図 8 にバルブ部品の円筒部分の高精度加工を作業者の 知識を組み迄むことによって実現した加工制御システムの 構成図を示す。この工程では, 内径寸法とテーパ寸法の 2 項目が要求精度が高く, 設備の稼動状態の微妙な変化で, この 2 つの項目の精度が変化し, しかも2 項目問の相関が 弱く, 品質の安定化に苦慮していた. 作業者は段取り作業 時, 休憩時間後, 砥石ドレス後などの稼働状態の変化を注 視し, 経験則によって蓄積された対処方法を用いて操作を 行っていた。この方法では, 作業者の変化により不良品の 発生状況が異なるため作業者が特定され, 入出力関係のシ ンプルな相関づけが難しく，改善が進まない課题があっ た。そこで，作業者のノウハウを知識として抽出し，この 知識を制御アルゴリズムに組み込んだ加工制御システムを 開発した.

入力情報の可視化および作業者の処理方法の抽出のため に, 設備の稼動状態, 部品の加工データ, および環境変化 を時系列に長期間記録し，この情報から作業者の制御方法 を再現し，入力情報として 13 項目の寸法デー夕と設備の 稼動情報, 出力情報として作業者の処置を含む 10 項日, 処理を決定するための 39 の制御知識を特定した。この結 果に基づき, 多入力多出力の制御システムを開発した。

開発結果の一例を図 9 に示す。設備の状態変化を確実 に計測することにより制御知識から特定されるさまざまな 制御が頻繁に起こり, 加工狙い值に対する追従性と工程能

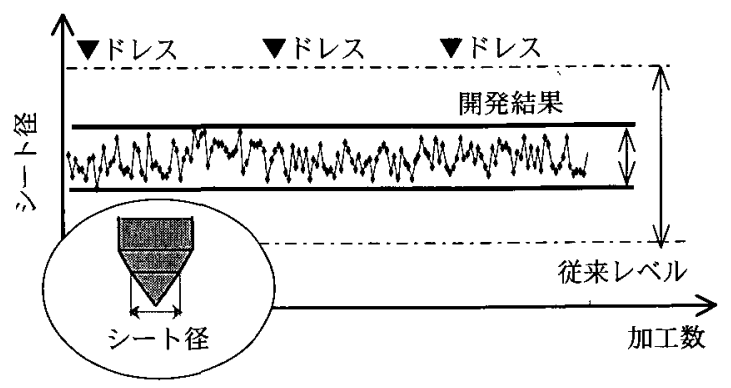

図 7 画像インライン計測技術導入結果

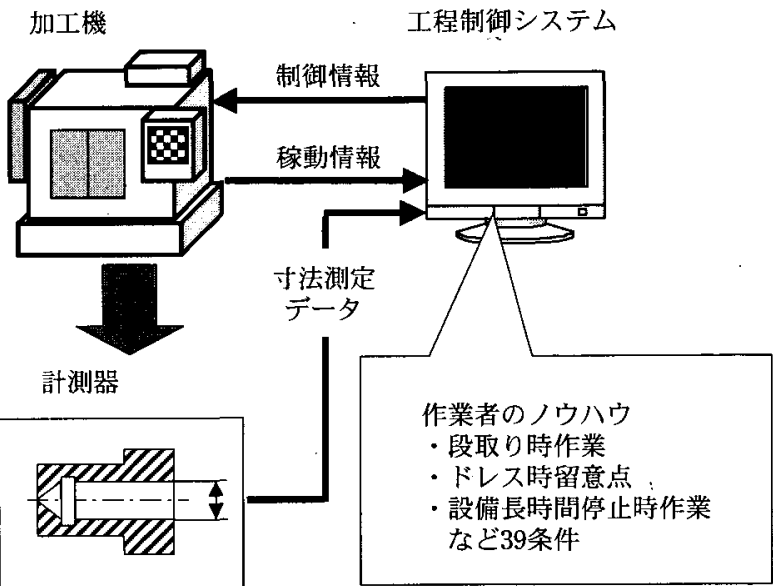

図 8 作業者知識を組み込んだ加工制御システム

力の高い良好な結果が得られた。制御則が特定されたこと によって作業者への依存性がなくなり, 長期間安定的な高 精度加工が可能となった. 図 9 に示す事例では, 設備停止 時, 砥石交換時などの非定常作業時の微妙な加工条件の補 正を経験則により行っていた状況が, 設備の稼働情報, 寸 法測定データなど常時収集されるデータから総合的に判断 し, 頻繁に制御が行われ, 品質が安定している状況となっ ていることを示している.

本手法は, 従来作業者の技能・ノウハウで対応せざるを 得ない技術化が困難な高品質化の主要因に適用する場合に は有効である. しかし作業者の技能, ノウハウの技術化は 非常に難しい技術課題であり, 本事例でもいちばん苦労し た点である. 知識抽出の技術開発の進歩が展開には不可欠 である.

\section{4 インテリジェント視覚モジュール}

不良品の流出防止の最後の砦として外観検查があるが, 検査部位の多さと対象機種の多さゅえに, 作業者のもつ認 識能力の高さと柔軟性に勝る合理化が遅れていた．しか し, 生産拠点の多拠点化・グローバル化の展開する中で, 同一品質を確保するために品質向上の視点から人的な要因 を排除する安価な自動化が求められてきた，そのために図 10 に示すように，ロボットにカメラをもたせ，多部位お よび多種類の製品に対しても柔軟かつ迅速に対応可能なイ 

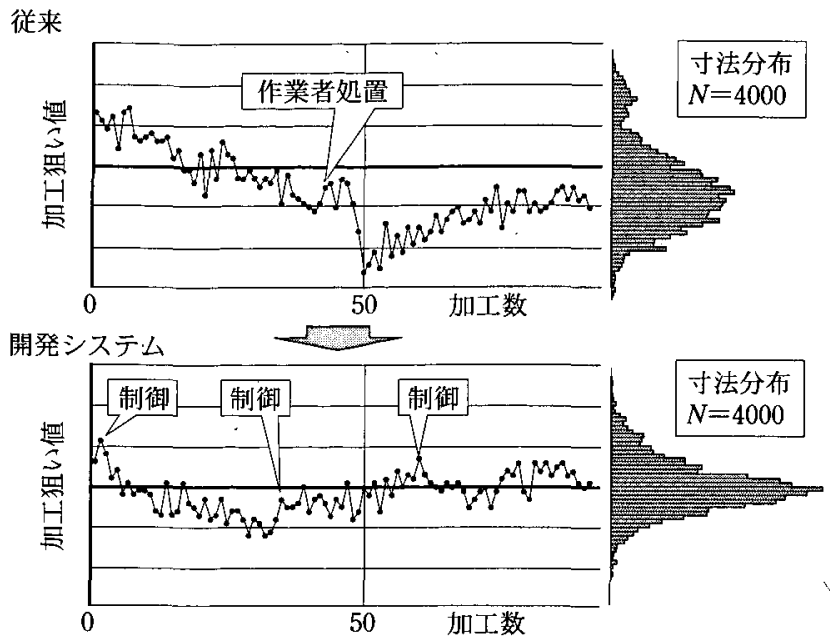

図 9 作業者知識を組み迄んだ加工制御システム導入結果

ンテリジェント視覚モジュールを開発・導入し，効果をあ げ始めている゙ .

製品最終外観検査工程では，全方位から 30 -50力所も の検査項目，組立ラインに同期した作業速度が求められる ので，柔軟から高速な検査動作が必要となる。そのために カメラ付き多関節ロボットが設備構成としては望ましい が，製品の外観形状を高速で特定するためには，カメラが 停止せず移動しながらワークの位置・姿勢を正確に認識し なければならない、ロボットの制御は停止点の位置は保証 されるが，動作中の通過点は指示してもロボットが高速動 作するために指示点近傍で一致することが困難であり，そ れを解消するために，動作中の通過点を指示した姿勢で正 しく通過させることのできるロボットの経路生成手法を開 発し，移動しながら正しく製品形状を特定できるようにし た. 外観検査では 30〜200 品番へ対応することが求めら れ, しかも新製品追加, 製品変更も多いため, ロボットの 経路ティーチングの簡易化が不可欠であり，このための ティーチング部も開発した。複数の画像抽出制御ポイント を正しく通過するための画像処理教示と，ロボットの経路 教示を融合させて計算できる構造を特徴としている。この 結果, 平均 35 力所の検查を平均 17 秒で処理, ティーチン グ時間も 5 分/力所と従来比 $1 / 5$ を実現でき，最終外観検 查工程の自動化を実現した。

安定的な不良品流出防止の関所として，グローバルに拡 大展開するには，さらなるコストダウン，人を活かした代 替技術開発が期待される。
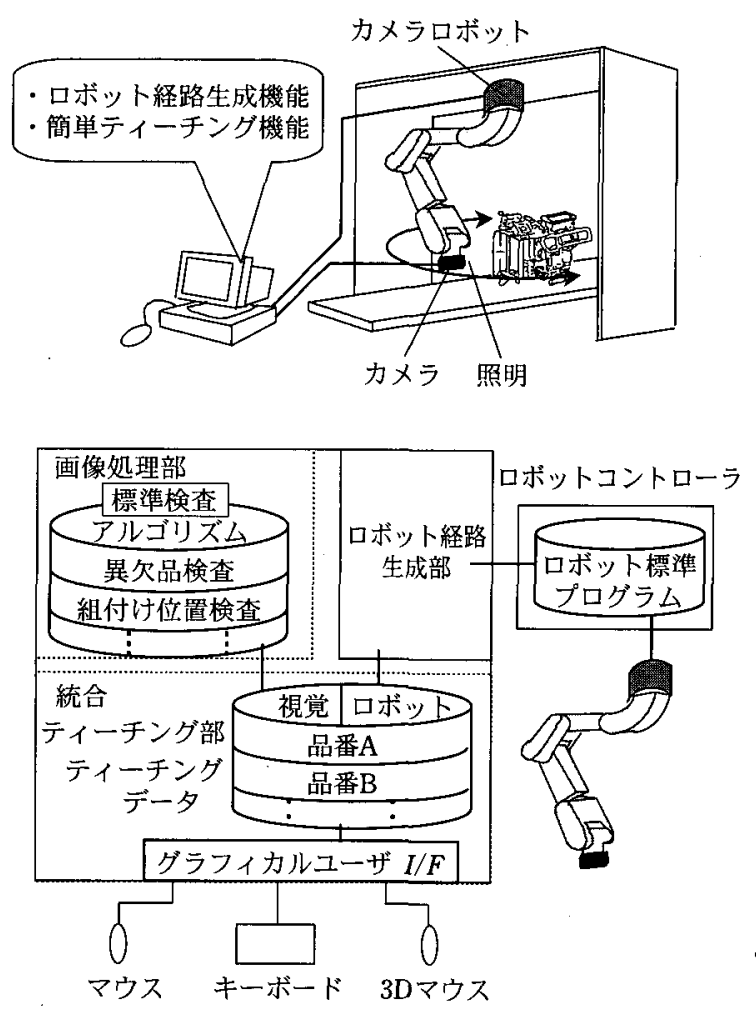

困 10 インテリジェント視覚モジュールの構成

\section{4.お おりに}

高品質化は，製品設計技術および生産技術の構成因子が 複雑に絡み合い，統合化された，巨大かつ複雑なシステム の最適化を四るものであり，一朝一夕に構築できるもので はない，原理・原則・現地・現物に根付いた高品質化に向 けての地道な活動が不可欠であり，それを大量・高速・高 頻度な特長を有する情報技術と融合することによってこ そ，初めて情報技術を活かした高品質なものづくりが実現 される.この考え方に今後も立脚して高品質なモノづくり の技術開発に取り組んでいく.

\section{参 考 文 献}

1）新山英輔：鋳物， 54（1982） 30 .

2）飯見秀紀，加藤鋭二：日本鉡造工学会第 139 回全国講演大会 講演概要集 (2001) 138.

3）山本 宗ほか：インライン画像計測を用いた高精度加工シス テム, 日本機械学会, 2002 年次大会講演論文集 (V), (2002) 349 .

4）木村博志ほか：インテリジェント視覚モジュールの開発，日 本ロボット学会, 第 21 回学術講演会講演概要集, 3K15 (2003). 